\title{
Impact of Leadership on Human Resources to Achieve a High Level of Job Satisfaction in Higher Education Institutions
}

\author{
Noman Raheem Mastoi \\ Shaheed Benazir Bhutto University of Veterinary \& Animal Sciences, Sakrand-67210, Sindh, Pakistan \\ E-mail: mastoi.noman@gmail.com
}

\begin{abstract}
The leadership and human resources are two major factors, which cannot be ignored in the substantial growth of higher education institutions. A person joins a higher education institution with motivation and certain intentions, which include job security, good income, and better prospects for professional and personal development in the future. It is the responsibility of the leadership of the institution to be familiar with these basic facts and to take such steps, which not only take the business to the next level, but it should also encourage the employees to push hard for their professional and personal growth. Nevertheless, it is not easy to achieve the objective of lacking proper administration and collective efforts of the workforce. The purpose of this review paper is to highlight the role of leadership, which directly or indirectly makes an impact on the efficiency of human resources to achieve a high level of job satisfaction in Higher Education Institutions.

Key words

Leadership, Job Satisfaction, Human Resources, Human Resource Management, Higher Education Institutions

Received: 03 Jul $2020 \quad$ (C) The Authors 2020

Revised: 05 Aug $2020 \quad$ Published by Human Resource Management Academic Research Society (www.hrmars.com)

Accepted: $\quad 14$ Aug 2020 This article is published under the Creative Commons Attribution (CC BY 4.0) license. Anyone may Published Online: 22 Aug 2020 reproduce, distribute, translate and create derivative works of this article (for both commercial and non-commercial purposes), subject to full attribution to the original publication and authors. The full terms of this license may be seen at: http://creativecommons.org/licences/by/4.0/legalcode
\end{abstract}

\section{Introduction}

Higher education is contributing to every aspect of the professional, technical, and social sector for its long term development through dynamic literature and research. This phenomenon is promoting the institutions to grow day by day in this competitive era. Strong competition amongst the higher education institutions and their purpose to reach top positions among the world ranking institutions make the human resource management in universities just as challenging as it is in the private sector (Sarip \& Royo, 2014), which is pushing the institutions to provide quality education of international standard, and remarkable services to the stakeholders.

As a matter of fact, it is visionary commitment, accomplishments, and behavior of the leadership that attracts and motivates the talent regardless of gender, race, religion, and nationality to join and contribute to the development of the industry. This also implies the responsibility to the leadership to extend every support to the employees in general, which may be needed to address their concerns with regard to job satisfaction and their personal growth because satisfied human resources would produce higher performance in the best possible time, which leads to amplify productivity. Whereas, lacking job satisfaction results in a low level of employee dedication, which will affect productivity and the accomplishment of organizational objectives (Rast \& Tourani, 2012). Similarly, studies have shown that 
formal leadership qualities and behavior in higher education substantiate that leaders and leadership are essential to improve the learning and teaching, governance, significance, and success of institutions imparting higher education (Hofmeyer et al., 2015).

The leadership is extensively believed a significant element for the substantial growth, poor growth, breakdown, or failure of an organization (Oladipo et al., 2013; Northouse, 2015). The higher education institutions are not an exception in this case, where effective leaders and leadership behavior are considered critical for the academic and administrative performance of the institution. This becomes factual when higher education institutions face numerous challenges in terms of noteworthy decrease in public support, contradictory opinions about the purpose of higher education, opportunities presented by latest technologies for teaching and learning, and a competitive global economy changing at a rapid pace (Gigliotti \& Ruben, 2017).

As the higher education sector is expanding worldwide, and institutions are emerging with high increase in the number of students, these institutions also require high increase in human resources for proper management and constant growth. Consequently, leadership and human resource management studies are also in focus to improve the strategies to avoid inconsistency and flaws; and to maximize the productivity for the better future of higher education. This review paper has emphasized on the studies carried out in the past two decades to highlight the impact of leadership on human resources to achieve a high level of job satisfaction, which is believed to be the most important factor in the success of higher education institutions.

\section{Literature review}

\subsection{Leadership}

Leadership has been defined in more than 400 ways worldwide with respect to various fields of study (Sidik \& Hamid, 2017). Researchers have come together and established that leadership is about motivating and directing human resources to achieve organizational goals (Gregory, 2014; Mcmullen, 2013; Kumari \& Rachna, 2011). Many researchers have defined leadership in their own ways, like lqbal et al. (2015) have described as leadership is a process by which an executive can direct, guide, and influence the behavior and work of others towards the accomplishment of specific goals in a given situation. According to Lumby (2012) a leader is usually considered to be a person who holds a position of authority, or who has the charisma and dynamism to develop a vision and inspire others to follow it. US academic environment defined as a process of social influence in which a person can enlist the aid and support of others in the accomplishment of the common task (Wikipedia, 2020). Avolio et al. (2004) defined leadership in terms of characteristics, traits, and behavior focused on a clear vision, action, ethical relationship, trustworthiness, modeling the way, congruence, and collaboration. The relationship nature of leaders with employees influences their job satisfaction, positive relationships, turnover, well being of followers, and overall organization's performance (Boyatzis et al., 2012). Unsurprisingly, leadership behavior triggers an emotional response in the employees who lead and affects their performance ultimately (Hofmeyer et al., 2015).

Effective leadership starts with the primary aptitude to trust in him, which includes maturity, confidence, and knowledge that transforms into an intention and direction. Leadership is regarding developing ideas and thoughts, taking on responsibilities, and ambitions to take out the confidence of others (Ali, 2009). Studies have shown various styles in which a leader can perform effectively. Nevertheless, it is a constant pattern of behavior that characterizes a leader, and various leadership styles may affect the performance of the organization. The Success and growth, disappointment, and failure of the organizations have been largely attributed to the nature of the leader or leadership style of their organization (Oladipo et al., 2013). There is a need for effective leaders in today's organizations who are aware of complications of the speedily changing international environment. When the relationship between the leader and the employees is good, the effectiveness of the employees will be high, and they can achieve highly structured tasks, and the study further discovered that when the leaders involve other members of the team in discussion with great care, they work with the highly motivated team (Nanjundeswaraswamy and Swamy, 2014). 


\subsection{Role of Leadership in HEls}

In the 21st century, the importance of effective leadership and successful management of educational institutions have been progressively more recognized, because leaders keep their employees engaged in their work positively which is the fulfilling, affective and motivational state of professional wellbeing since engaged employees enthusiastically involve in their work with high levels of energy (Arokiasamy \& Tat, 2020). Leadership in higher education generally deals with the activities under which conduct and management of academics from planning and policymaking to the end of assessments (Slimane, 2012). However, educational leaders must be aware of their capacity to support social and economic growth and focus strategically on planning and practices to create short and long term opportunities for learning that will make a significant difference for individuals and their societies (Webber, 2016). The main duty of leadership involves the capacity to make the change happen. Leadership is increasingly supporting as a strategic and operational imperative within the industry to meet the raised demands and changed conditions (Røsdal, 2015). Leadership and management are considered two different, but compulsory elements of formal academic governance, individuals who play in these roles, influence the culture and learning and teaching in distinctive ways (Marshall et al., 2011).

The way leaders lead the human resources policies of an organization can influence employee's performance, when the employees receive interpersonal treatment from their leadership could have strong influence on the employee's perception of fairness which includes consideration of their opinions, supporting their personal interests, timely provision of feedback, explained decisions properly and applying decision making criteria constantly (Whitener, 2001). Hence, the supervisors in the organizations treat their employees fairly as they perform human resource practices and procedures that could enhance employee's trust in the supervisor and the organization, ultimately, which will affect the employee's level of organizational commitment positively (Laka-Mathebula, 2005).

A leader is a central figure in an institution, and leadership is the main factor connected to job satisfaction of human resources, which is linked to the process of motivation, communication, and interpersonal behavior that influence the employees to determine the organizational performance (Gregory, 2014). An organization is believed to be a good organization for the human resources where the relationship between the leader and subordinate staff is practiced at a high level because the researchers have also studied that employees are motivated by the leaders the way they treat them in an organization (Zabarauskaite, 2012; Yuliarini et al., 2012). Hence, it is believed that leaders should provide timely feedback to the employees on the job performance so that employees may be aware of their contribution to the organization and determine their job performance as it could be enhanced in the future, where leaders do not consider it worth to provide feedback to the staff or employees do not wonder to improve the performance or not affects the performance of the organization (Gregory, 2014; Branham 2005).

A leader should support the employees by increasing their confidence level through establishing good values and beliefs to motivate the human resources and to minimize the inefficiency of the organization (Memon et al., 2016). A leader should also be fair and unbiased towards human resources because when leaders treat the employees fairly, employees experience a high level of job satisfaction. Further leaders always make efforts to establish a strong relationship with the human resources (Lin \& Lin, 2011) so that employee's response the way they are being treated, therefore leaders must build the relationship of trust and loyalty with the employees so that employees would feel keenness and passion in their work environment and job performance that will lead the employees toward the high level of job satisfaction (Sidik, \& Hamid, 2017).

\subsection{HRM and Job Satisfaction in HEIS}

Employees are one of the key requirements of every organization because they execute a variety of functions as per their job description to run the institutions smoothly. Employees are the most essential and difficult to deal with because every person is born unique and have different characteristics. Secondly, human being manages and organizes the other resources (Vasitha \& Chauhan, 2011). Since the main purpose of higher education institutions is to provide quality education and quality services to the stakeholders, this key objective can be fulfilled through the skilled and talented human resources, and due 
to this reason, human resources are believed as the most valuable resources of an educational institution

(Teir \& Zhang, 2016).

Human resource management literature has commonly focused on commitment, job satisfaction, and organizational effectiveness (Burma, 2014). Human resource management is the institutional function that manages issues associated with all the employees in the institution who contribute individually and collectively in the accomplishment of the institution's objectives (CRS, 2011). It's a must for every institution to establish a separate department to manage human resources promptly and efficiently. A policy for improving the quality of manpower efficiency to drive higher value for the organizations has become the main focus (Marimuthu et al., 2009). Human Resource policies can be utilized as a vibrant tool towards success. The best strategic arrangement of employees can be achieved through efficient human resource practices (Hussain \& Ahmed, 2012). This approach is expanding worldwide, and institutions are imparting various study programs on Human Resource Management to produce good quality HR professionals for every industry.

According to Androniceanu (2011), human resource management of the organizations should consider the motivation and job satisfaction of employees as the main priorities, so they can achieve medium and long term sustainable growth. However, researchers have conducted series of studies to examine the dimensions or elements that generate the level of satisfaction and dissatisfaction among the employees, and these dimensions include recognition of their hard work in terms of cash prizes or rewards, fair and timely promotions, opportunities for personal development, work environment, appropriate salary package, employees contribution to the organizational growth, provision of social welfare benefits and developing human relations, and most importantly the leaders or leadership of the organizations (Androniceanu, 2009; Karaalioğlu, \& Karabulut, 2019).

The researchers Vasitha \& Chauhan, (2011) made an attempt and revealed that human resource management is the study of human nature, their needs and objectives in an organization, being aware of the fact that if these human requirements are ignored, it could lead the failure of the institution to achieve the set goals for the management of the institution. Therefore, leaders in higher education institutions go a long way to improve the quality and satisfaction rate of the workforce. Hence it was recommended by the researchers that the leaders should deal with employees individually and collectively so that employees can be understood deeply, as every institution is making efforts to attract and retain the best talent from the specialist pool of human resources, so in this scenario leaders of the institutions should develop and utilize these talents up to optimum level.

Jeet \& Sayeeduzzafar (2014) believe that job satisfaction is an approach that can be attained by observing and experiencing the various aspects of likes and dislikes with the work environment. An employee may define the level of satisfaction with respect to the job. Job satisfaction is a critical indicator that shows the feeling of employees about the work and level of contentment with the job. Satisfied employees are also attributed to the overall performance of the organization; hence employee job satisfaction is the key to success for the organizations. According to Bogdanova et al. (2008), human resource management policies and practices are to develop and allocate the human resource in the best possible ways to achieve the organizational long term goals in exchange of benefits and favorable work environment that motivates the employee's and boosts their job satisfaction and performance.

\section{Discussions}

As leadership can be defined in many ways, it also can be practiced in different styles. In my viewpoint, all the definitions conclude that leadership is the central figure who has the power to reinforce the abilities of others and keeps everyone involved and guide them to accomplish the common task in any circumstances. A leader may adopt any style depending on the circumstances with the unchanged objective in the field of Higher Education to improve the performance and constant growth facing the challenges as one particular style does not guarantee that it will be beneficial for every institution. Therefore, it's the responsibility of good leadership to act accordingly and utilize the manpower to strengthen the overall performance.

Human behavior plays a pivotal role in the overall performance of an organization. It enables one to satisfy at least some of their individual needs, who work in it (Vasitha \& Chauhan, 2011). Employee's salary 
is another important factor, particularly for the motivation of human resources (Androniceanu, 2011). Definitely, salary is a matter of concern for every employee; however, many people don't consider it important. When it comes to employment, recruiting officers hire suitable candidates as per the requirement of the institutions; similarly, candidates also look for definite possibilities for their professional and personal growth.

Employees will be encouraged to give their best, leading to higher job satisfaction and organizational effectiveness, when opportunities for growth and development of skills are presented (Burma, 2014). It is good practice to provide every single chance to the employees for their self development and job satisfaction. However, they will feel secure when their services are recognized. According to Ababneh (2020), researchers have studied the connection between the trust and turnover intentions of the employees, and empirical findings revealed that high trust is most likely to act as a moderator to decrease the turnover intentions. Here leadership role makes a difference by recognizing the efforts of the employees along with providing the best possible opportunities by investing in human resources and establishing the relationship of trust that will enhance the overall performance of the institution. Newcomers are a good example to justify this fact. When they start their employment career, they look for an institution where they can practice their expertise in a better way and can gain good experience and opportunities for a better future. They struggle to gain the attention of the leadership with the hope that their contribution will be recognized, and they hardly look for salary instead. Besides the recognition, they can also be rewarded with an increase in their salary and other benefits as per their performance. This is how leadership can influence the employees to do their best. Conceptual framework of the leadership role that impacts the performance of human resources to achieve a high level of job satisfaction, and efficiency of the institution is shown in figure 1 .

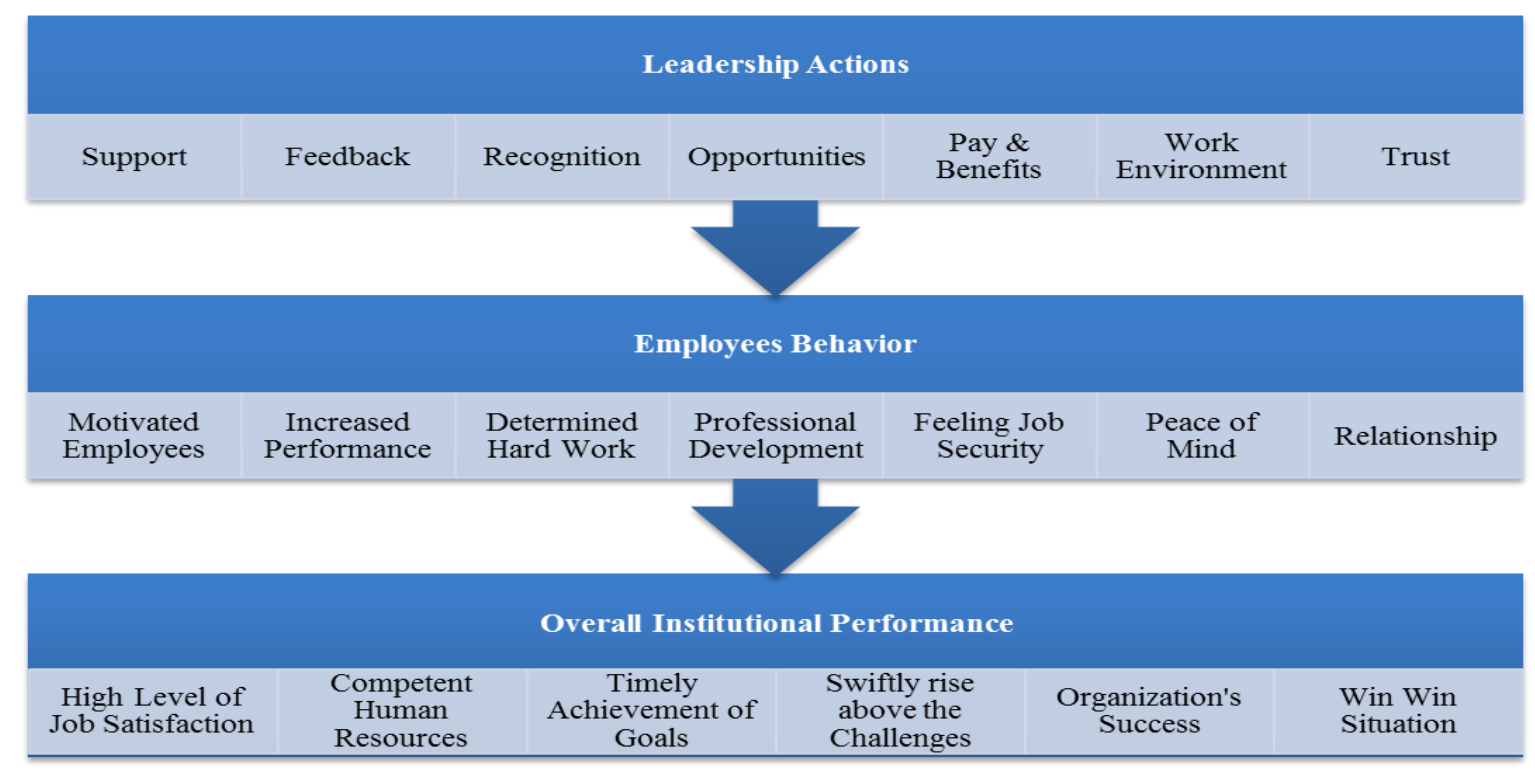

Figure 1. Conceptual framework

There is another significant factor by which leadership can also boost the performance of an individual and overall performance of the institution by developing a strong relationship among the employees and institution. Influencing people to follow for the general cause is a relationship of trust between the leader and the human force. Therefore, the relationship between these two requires more attention to achieve the desired results in the estimated time. This relationship also defines the institution's environment, interpersonal links amongst the employees, and the ability for long term achievements, if the relations are well established then a leader can overcome difficult challenges easily with the support of trained manpower. 


\section{Conclusions}

In the higher education sector, leadership and human resources are two sides of a coin, both depend on each other, and both define each other equally. Leaders need followers who can achieve challenging targets, and followers need a leader who can satisfy their needs. It generates a relationship of trust and leads both to the satisfaction of each other in an appropriate manner. For overall performance of the institutions, it is necessary for the leadership to recognize the efforts of employees; their professional, social and personal needs may be incorporated in the policies and implemented for their job satisfaction; and to invest on employees to keep them equipped with the latest knowledge of technology and skillset required for their competency level on the job.

\section{References}

1. Ababneh, K. I. (2020). Effects of met expectations, trust, job satisfaction, and commitment on faculty turnover intentions in the United Arab Emirates (UAE). The International Journal of Human Resource Management, 31(2), 303-334.

2. Ali, A. (2009). The role of leadership in human resource management: a comparative study of specific public and private sectors in Pakistan. Journal of Management and Social Sciences, 5(2), 180-194.

3. Androniceanu, A. (2011). Motivation of the human resources for a sustainable organizational development. Economia Seria Management, 14(2), 425-438.

4. Androniceanu, A. (2009). New Public Management Model Based on an Integrated System Using The Informational And Communication Technologies, Administration and Public Management Review, 13, 13-25.

5. Arokiasamy, A., \& Tat, H. (2020). Exploring the influence of transformational leadership on work engagement and workplace spirituality of academic employees in the private higher education institutions in Malaysia. Management Science Letters, 10(4), 855-864.

6. Avolio, B. J., Gardner, W. L., Walumbwa, F. O., Luthans, F., \& May, D. (2004). Unlocking the mask: A look at the process by which authentic leaders' impact follower attitudes and behaviors. Leadership Quarterly, 15(6), 801-823.

7. Bogdanova, A., Enfors, H., \& Naumovska, S. (2008). Work Environment Stressors-The link between employees' well-being and job performance?. Bachelor Thesis within Business Administration, Jonkoping University.

8. Boyatzis, R. E., Passarelli, A. M., Koenig, K., Lowe, M., Matthew, B., Stoller, J. K., \& Phillips, M. (2012). Examination of the neural substrates activated in memories of experiences with resonant and dissonant leaders. Leadership Quarterly, 23(2), 259-272.

9. Branham, L. (2005). The 7 Hidden Reasons Employees Leave. Concordville, Pennsylvania: Soundview Executive Book Summaries.

10.Burma, Z. A. (2014). Human resource management and its importance for today's organizations. International Journal of Education and Social Sciences, 1(2), 85-94.

11.Catholic Relief Services. (2011). Human Resources. United States Conference of Catholic Bishops. Baltimore: CRS publications.

12.Gigliotti, R. A., \& Ruben, B. D. (2017). Preparing higher education leaders: A conceptual, strategic, and operational approach. Journal of Leadership Education, 16(1), 96-114.

13.Gregory, K. (2014). The importance of employee satisfaction. The Journal of the Division of Business and Information Management, 5, 29-37.

14.Hofmeyer, A., Sheingold, B. H., Klopper, H. C., \& Warland, J. (2015). Leadership in learning and teaching in higher education: Perspectives of academics in non-formal leadership roles. Contemporary Issues in Education Research, 8(3), 181-192.

15.Hussain, M., \& Ahmed, M. (2012). Mostly discussed research areas in human resource management (HRM) - a literature review submitted to management journals. International Journal of Economics and Management Sciences, 2(3), 10-17.

16.Iqbal, N., Anwar, S., \& Haider, N. (2015). Effect of leadership style on employee performance submitted to open access journals. Arabian Journal Business Management Review, 5(5), 1-6. 
17.Jeet, V., \& Sayeeduzzafar, D. (2014). A study of HRM practices and its impact on employees job satisfaction in private sector banks: A case study of HDFC Bank. International Journal of Advance Research in Computer Science and Management Studies, 2(1), 62-68.

18.Karaalioglu, Z. F., \& Karabulut, A. T. (2019). The Mediating Role of Job Satisfaction On The Relationship Between Perceived Organizational Support and Job Performance. Business \& Management Studies: An International Journal, 7(2), 1022-1041.

19.Kumari, N., \& Rachna, M. (2011). Job Satisfaction of the Employees at the Workplace. European Journal of Business and Management, 3(4), 11-30.

20.Laka-Mathebula, M. R. (2005). Modelling the relationship between organizational commitment, leadership style, human resources management practices and organizational trust (Doctoral dissertation, University of Pretoria), P-8.

21.Lin, S., \& Lin, J. S. (2011). Impacts of coworkers' relationships on organisational commitment and intervening effects of job satisfaction. African Journal of Business Management, 5(8), 3396-3409.

22.Lumby, J. (2012). What do we know about leadership in higher education? Submitted in review paper series. London: The Leadership Foundation for Higher Education.

23.Marimuthu, M., Arokiasamy, L., \& Ismail, M. (2009). Human capital development and its impact on firm performance: evidence from developmental economics. The Journal of International Social Research, 2(8), 265-272.

24.Marshall, S., Orrell, J., Cameron, A., Bosanquet, A., \& Thomas, S. (2011). Leading and managing learning and teaching in higher education. Higher Education Research \& Development, 30(2), 87-103.

25.Mcmullen, T. (2013). Eight recommendations to improve employee engagement. Journal of Compensation and Benefits, 23-29.

26.Memon, M. A., Ting, H., Salleh, R., \& Ali, J. K. (2016). Level of stress and job satisfaction among call operators: A case of Malaysian telecommunication sector. International Review of Management and Marketing, 6(3), 442-447.

27.Nanjundeswaraswamy, T. S., \& Swamy, D. R. (2014). Leadership styles. Advances in Management, $7(2), 57-62$.

28.Northouse, P. G. (2015). Leadership: Theory and practice (7th ed.). Thousand Oaks, CA: Sage.

29.Oladipo, K. S., Jamilah O., Abdul daud, S., Jeffery, L. D., and Salami, D. K. (2013). Review of leadership theories and Organizational performances, International Business Management Journal, 7(1), 50-54.

30.Rast, S., \& Tourani, A. (2012), Evaluation of employees' job satisfaction and role of gender difference: an empirical study at airline industry in Iran. International Journal of Business and Social Science, 3(7), 91-100.

31.Røsdal, T. (2015). Challenges of leadership in Higher Education Institutions paper presented in track 1 at the EAIR 37th Annual Forum in Krems, Austria.

32.Sarip, A., \& Royo, M. A. (2014). Strategic HR in higher education institutions in Malaysia and Denmark. International Journal of Trade, Economics and Finance, 5(1), 60-64.

33.Sidik, M. H. M., \& AB Hamid, M. R. (2017). Theoretical support for staff satisfaction in higher education institutions: A conceptual framework. Journal of Quality Measurement and Analysis JQMA, 13(2), 1-16.

34.Slimane, M. (2012). Role and relationship between leadership and sustainable development to release social, human, and cultural dimension submitted to International Conference on Leadership, Technology and Innovation Management. Procedia - Social and Behavioral Sciences, 41, 92-99

35.Teir, R. A. A., \& Zhang, R. Q. (2016). The current Practices of Human Resource Management in Higher Education institutions in Palestine. Journal of Human Resources Management and Labor Studies, $4(1), 65-83$.

36.Vasitha, M. L., \& Chauhan, B. S. (2011). Role of HRM \& OB in today's educational institution/university administration. International Journal of Management Technology, 19, 17-22.

37.Webber, C. F. (2016). Higher education administration, and leadership: current assumptions, responsibilities, and considerations. Research in Educational Administration \& Leadership, 1(1), 61-84. 
38.Whitener, E. M. (2001). Do "high commitment" human resources practices affect employee commitment? A cross-level analysis using hierarchical linear modelling. Journal of Management, 27(5), 515535.

39.Wikipedia. (2020). Leadership. Retrieved March 15, 2020 from http://en.wikipedia.org/wiki/ Leadership.

40.Yuliarini, S., Kamariah, N., Mat, N., \& Kumar, P. (2012). Factors affecting employee satisfaction among non-teaching staff in higher educational institutions in Malaysia. American Journal of Economics, 6 , 93-96.

41.Zabarauskaite, R. (2012). Job satisfaction factors among university staff. Retrieved from https://www.eurofound.europa.eu/publications/article/2012/job-satisfaction-factors-among-universitystaff 